\title{
MEMPERKUAT PEMBERDAYAAN MASYARAKAT DESA SEBAGAI AKTUALISASI OTONOMI DESA MELALUI DEREGULASI KELEMBAGAAN YANG MENGURUS DESA
}

\author{
Endang Retnowati*, Ardhiwinda Kusumaputra, Noor Tri Hastuti \\ Fakultas Hukum Universitas Wijaya Kusuma Surabaya \\ Jl. Dukuh Kupang XXV No.54, Dukuh Kupang, Kec. Dukuhpakis, Kota Surabaya, 60225 \\ endangretnowati49@yahoo.co.id
}

\begin{abstract}
Villages are an inseparable part of the Unitary State of the Republic Indonesia. Based on Law Act Number 6 of 2014 concerning Villages, it provides directions for strengthening the empowerment of village communities. However, there are several derivative rules that actually hinder the actualization of rural community empowerment. Create overlapping regulation on each other, so that it has an impact on the slowness of community empowerment. There are two formulations of the problems. First, why is it necessary to make efforts to improve village community empowerment? Second, how are legal efforts to optimize village community empowerment? Empowerment of rural communities is an effort to build villages so that they are more developed and of higher quality. Currently, the empowerment effort is also hampered by regulations that actually create legal uncertainty, especially at the level of Ministerial Regulation. Therefore, deregulation is an integrated effort to create legal certainty that can increase the empowerment of rural communities.
\end{abstract}

Keywords: Rural Community Empowerment; Village Autonomy; Deregulation.

\begin{abstract}
Abstrak
Desa merupakan bagian tidak terpisahkan dari Negara Kesatuan Republik Indonesia. UndangUndang Nomor 6 Tahun 2014 tentang Desa, memberikan arah pengaturan penguatan pemberdayaan masyarakat desa. Namun, terdapat beberapa aturan turunan yang justru menghambat aktualisasi pemberdayaan masyarakat. Menimbulkan aturan yang saling tumpang tindih, sehingga berdampak pada lambatnya pemberdayaan masyarakat. Terdapat dua rumusan masalah yang diangkat. Pertama, mengapa diperlukan upaya untuk melakukan peningkatan pemberdayaan masyarakat desa? Kedua, bagaimana upaya hukum dalam mengoptimalkan pemberdayaan masyarakat desa? Pemberdayaan masyarakat desa merupakan upaya untuk membangun desa agar lebih berkembang dan berkualitas. Saat ini, upaya pemberdayaan tersebut juga terhambat oleh regulasi yang justru menimbulkan ketidakpastian hukum, khususnya pada tingkatan Peraturan Menteri. Oleh karena itu, deregulasi menjadi upaya terpadu agar tercipta kepastian hukum yang mampu meningkatkan pemberdayaan masyarakat desa.
\end{abstract}

Kata Kunci: Pemberdayaan Masyarakat Desa; Otonomi Desa; Deregulasi. 


\section{A. Pendahuluan}

Desa merupakan bagian dari Negara Kesatuan Republik Indonesia (NKRI). Ditinjau dari aspek historis, keberadaan Desa, bukanlah bentukan dari Negara. Desa merupakan bentuk alami yang terlahir dari kesepakatan masyarakat. Bahkan, Desa menjadi ide terbentuknya suatu pemerintahan modern, termasuk Negara (Pakaya, 2016).

Secara sosiologis, kehidupan masyarakat di Desa, selalu erat kaitannya dengan nilai kekeluargaan. Membangun sinergi antar individu, sehingga mampu menjadi suatu kelompok masyarakat yang mandiri (Maschab, 2013). Hal inilah yang melahirkan suatu pemaknaan secara filosofis bahwa Desa dan masyarakatnya adalah satu kesatuan. Pertumbuhan dan kemajuan Desa, dari berbagai aspek, sangat bergantung dari masyarakatnya.

Berdasar pada Pasal 18B Undang-Undang Dasar Negara Republik Indonesia Tahun 1945 (selanjutnya disebut UUD NRI Tahun 1945), dapat dimaknai bahwa Negara Indonesia, melalui Pemerintah, mempunyai tanggungjawab untuk mengakui dan menghormati keberadaan Desa, khususnya bagi Desa yang masih lekat dengan nilai tradisional atau adat istiadat. Bentuk pengakuan dan penghormatan tersebut, ditunjukkan dengan penguatan dari segi regulasi, dan pembangunan wilayah Desa.

Undang-Undang Nomor 6 Tahun 2014 tentang Desa (selanjutnya disebut UU No. 6 Tahun 2014), menjadi dasar hukum atas keberadaan Desa dan Desa Adat. Pasal 1 angka 1, telah memberikan penyeragaman istilah. Meskipun demikian, tetap perlu ada perbedaan dalam memahami Desa dan Desa Adat, khususnya dari segi nilai tradisional / adat istiadatnya.

Pada penulisan ini, difokuskan pada Desa yang bukan Desa Adat (menurut Peneliti, Desa yang dimaksud lebih tepat disebut Desa Modern/Hybrid). Disebut dengan hybrid, sebab di dalamnya telah memasukan unsur pemerintahan modern, dengan mempertahankan beberapa nilai adat yang dianggap masih relevan untuk digunakan.

Permasalahan dalam hal peningkatan kualitas masyarakat, melalui partisipasi maupun pemberdayaan, dengan peran lembaga kemasyarakatan desa, banyak terjadi pada tataran normatif. Banyak regulasi yang saling tumpang tindih. Menimbulkan adanya konflik norma. Secara yuridis, UU No. 6 Tahun 2014, juncto PP No. 43 Tahun 2014 (beserta perubahannya), telah memberikan arah pengaturan bahwa Desa harus mampu berdikari (Suharto, 2018). Guna mewujudkan tujuan tersebut, maka salah satu upaya yang ditempuh adalah melalui pemberdayaan masyarakat desa.

Namun, banyak peraturan turunannya, khususnya pada tingkat kementerian, seperti PermenDesa dan PDTT No. 17 Tahun 2019 tentang Pedoman Umum Pembangunan Pemberdayaan Masyarakat Desa, Permendagri No. 18 Tahun 2018 Tentang Lembaga Kemasyarakatan Desa dan Lembaga Adat Desa, maupun PermenSos No. 15 Tahun 2019 tentang Karang Taruna, justru tumpang tindih. Menjadikan adanya ketidakpastian hukum dalam implementasi pemberdayaan masyarakat desa melalui peran kelembagaan desa. Belum lagi, jika ditambah dengan berbagai Peraturan Daerah, Provinsi maupun Kabupaten/Kota yang menjadi dasar acuan dalam pelaksanaan pemberdayaan masyarakat desa.

Ditinjau dari aspek sosiologis, masyarakat mengalami kendala dalam memahami regulasi yang beragam. Kelembagaan di tingkat desa, khusunya yang termasuk dalam Lembaga Kemasyarakatan Desa, juga menjadi kurang mendapat kepastian hukum dalam menjalankan perannya. Oleh karena itu, ditinjau dari nilai kemanfaatan dan kepastian hukum, maka perlu adanya suatu upaya dalam mengoptimalkan pemberdayaan masyarakat Desa (Barniat, 2019).

Upaya deregulasi menjadi salah satu alternatif dalam penguatan pemberdayaan masyarakat desa. Deregulasi adalah bentuk pengurangan berbagai peraturan yang seharusnya tidak perlu ada, dan justru menghambat terlaksananya pemberdayaan masyarakat. Melakukan penyederhanaan atas aturan yang dapat menimbulkan ketidakpastian hukum dan menghambat (Chandranegara, 2019). Mengingat pula, bahwa eksistensi Desa hybrid, sebagai poros kekuatan pembangunan nasional, seharusnya mampu mempunyai akses secara langsung melalui kementerian. 
Mengurangi jalur peraturan hirarkis yang justru menghambat terciptanya peningkatan kualitas masyarakat di desa.

Sebelumnya juga terdapat tulisan jurnal yang membahas dengan judul "Pengembangan Model Partisipasi Masyarakat dalam Penyelenggaraan Pemerintahan Desa di Kabupaten Banyumas" (Pamuji, 2017). Secara konseptual, perbedaan mendasar dengan penulisan ini adalah pada gagasan yang ditawarkan. Penulisan tersebut lebih pada bentuk pengembangan model melalui optimalisasi struktural tingkah bawah, seperti Rukun Tetangga, Rukun Warga, Badan Permusyawaratan Desa. Pada penulisan ini, lebih kepada bentuk penyederhanaan peraturan, yang nantinya lebih difokuskan pada naungan satu kementerian.

Guna memberikan kejelasan arah kajian, dalam penulisan ini terdapat dua rumusan permasalahan yang diangkat. Pertama, mengapa pada setiap sektor kementerian turut membuat aturan terkait dengan pemberdayaan masyarakat desa melalui lembaga kemasyarakatan desa? Kedua, bagaimana bentuk upaya hukum yang dilakukan dalam penguatan pemberdayaan masyarakat desa?

\section{B. Pembahasan}

\section{Eksistensi Peraturan Sektoral Kementerian tentang Pemberdayaan Masyarakat Desa melalui Kelembagaan Desa}

Negara, berdasar pada UUD NRI 1945, mempunyai tanggungjawab untuk mengatur dan mengurus segala aspek kehidupan masyarakat. Apabila dihubungkan dengan konsep dasar tentang Hak Asasi Manusia, Negara, melalui pemerintahannya harus melindungi, memenuhi, dan menghormati hak-hak dasar masyarakatnya (Syafi'ie, 2012). Menjadi relevan, ketika Pemerintah menyusun serangkaian program yang bertujuan untuk meningkatkan kualitas hidup masyarakatnya, dengan tetap memperhatikan hak-hak dasarnya. Salah satunya adalah dengan adanya pemberdayaan masyarakat melalui peran kelembagaan.

Secara struktural, berdasar pada Pasal 4 ayat (1) UUD NRI 1945, kekuasaan pemerintahan berada di tangan presiden. Pelaksanaannya, dibantu oleh menteri-menteri yang membidangi urusan masing-masing, sebagaimana telah dipertegas dalam Pasal 17 UUD NRI 1945. Secara filosofis, pembidangan ini, dimaksudkan untuk mempermudah pelaksanaan urusan pemerintahan, khususnya dalam hal sistem presidensil. Para menteri itulah, yang berdasar pada Undang-Undang Nomor 39 Tahun 2008 tentang Kementerian Negara (selanjutnya disebut UU No. 39 Tahun 2008), memimpin masing-masing kementerian sesuai dengan pembidangan. Pada dasarnya, secara konstitusional, menjadi hak Presiden untuk menentukan pengisian jabatan Menteri. Berhak pula untuk memberikan tugas-tugas pemerintahan, yang berorientasi pada tujuan negara (Noviantika \& Taufiq, 2021).

Berdasar pada Peraturan Presiden Nomor 68 Tahun 2019 tentang Organisasi Kementerian Negara (dan perubahannya yang selanjutnya disebut Perpres No. 68 Tahun 2019), secara khusus juga telah memberikan dasar tentang lingkup tugas kepada 34 kementerian. Melihat pada Kementerian Desa dan PDTT, Kementerian Dalam Negeri, Kementerian Kesehatan dan Kementerian Sosial, berdasar pada Pasal 2 ayat (2) dan (3); Pasal 5 ayat (3), berada pada pembagian kelompok yang berbeda. Kementerian Dalam Negeri berada pada kategori Kelompok I, dengan maksud urusan pemerintah yang nomenklaturnya disebutkan secara tegas dalam UUD NRI 1945. Berbeda dengan Kementerian Desa dan PDTT, dan Kementerian Sosial, yang dikategorikan sebagai Kelompok II, dengan maksud yang pembidangannya atau ruang lingkup urusannya, disebutkan dalam UUD NRI 1945. Adanya pengelompokan tersebut, bukan berarti secara mutlak masing-masing kementerian bekerja sendiri-sendiri. Pelaksanaan fungsi kementerian, tetap harus melakukan koordinasi antar kementerian. Artinya, dimungkinkan adanya bentuk kerjasama lintas kementerian, yang dimaksudkan sebagai tujuan pembangunan nasional. 
Menariknya, pada ketiga kementerian tersebut, masing-masing turut memberikan pengaturan dalam aspek yang sama yaitu tentang pemberdayaan masyarakat desa, khususnya melalui kelembagaan di tingkat desa. Masing-masing kementerian, telah memberikan aturan yang berfungsi sebagai pedoman dasar dalam pelaksanaan pemberdayaan masyarakat. Dari segi kewenangan, apabila ditinjau dari segi kewenangan yang dimiliki, dengan berdasar pada UU No. 39 Tahun 2008 juncto Pasal 5 ayat (1) dan (2) Perpres No. 68 Tahun 2019, masing-masing lembaga memang mempunyai kewenangan untuk menyusun regulasi masing-masing.

Namun, apabila kewenangan tersebut terlalu memaksakan pada ego sektoral, dan tidak melakukan koordinasi dan konsolidasi antar lembaga kementerian, maka secara yuridis, dapat memberikan arah pengaturan yang tidak berkepastian hukum. Apalagi, jika secara substansi terdapat adanya materi muatan yang tumpang tindih antara satu dengan yang lainnya. Memicu adanya konflik norma secara horizontal, khususnya pada tingkat peraturan menteri.

Mencermati pada beberapa peraturan menteri berikut: a) Peraturan Menteri Desa, Pembangunan Daerah Tertinggal, dan Transmigrasi Nomor 17 Tahun 2019 tentang Pedoman Umum Pembangunan dan Pemberdayaan Masyarakat Desa (selanjutnya disebut PermenDesa dan PDTT No. 17 Tahun 2019); b) Peraturan Menteri Dalam Negeri Nomor 18 Tahun 2018 tentang Lembaga Kemasyarakatan Desa dan Lembaga Adat Desa (selanjutnya disebut Permendagri No. 18 Tahun 2018); dan, c) Peraturan Menteri Sosial Nomor 25 Tahun 2019 tentang Karang Taruna (selanjutnya disebut Permensos No. 25 Tahun 2019).

Ketiga aturan tersebut, sama-sama memuat pengaturan tentang pemberdayaan masyarakat desa melalui kelembagaan desa. Namun, materi muatan ketiganya, tidak menyebut adanya ketentuan tentang koordinasi antar kementerian dalam melakukan pembinaan kepada Desa, khususnya lembaga di tingkat desa dalam hal pemberdayaan masyarakat. Dapat secara khusus pada Pasal 89 PermenDesa dan PDTT No. 17 Tahun 2019 dan Pasal 13 Permendagri No. 18 Tahun 2018. Padahal, apabila mencermati pada Pasal 36, Pasal 38, dan Pasal 39 Permensos No. 25 Tahun 2019, mempertegas adanya bentuk pembagian pembinaan antara Kementerian Dalam Negeri dengan Kementerian Sosial.

Hal ini mengingat pula, bahwa pada dasarnya, lembaga di tingkat Desa yang termasuk dalam Lembaga Kemasyarakatan Desa, sebagaimana Pasal 6 Permendagri No. 18 Tahun 2018 antara lain meliputi: a) Rukun Tetangga (RT); b) Rukun Warga (RW); c) Pemberdayaan Kesejahteraan Keluarga (PKK); d) Karang Taruna; e) Pos Pelayanan Terpadu; dan, f) Lembaga Pemberdayaan Masyarakat.

Dimungkinkan juga untuk membentuk lembaga lain oleh Pemerintah Desa, sesuai dengan perkembangan dan kebutuhan. Artinya, dari dua lembaga yang ada, masih menunjukkan adanya bentuk ego-sektoral. Hal ini berpotensi untuk menimbulkan adanya ketidakharmonisan dalam penyusunan norma, maupun pelaksanaannya.

Namun, mencermati pada banyaknya regulasi yang ada, khususnya tentang pemberdayaan masyarakat desa dan kelembagaan desa, maka hal ini memang memunculkan berbagai problematika dasar. Ditinjau dari aspek ilmu perundang-undangan, peraturan perundangundangan memang dimaksudkan sebagai bentuk penataan. Tetapi, banyaknya regulasi, apalagi yang berada pada lingkup atau dibentuk oleh satuan yang berbeda, tidak menjamin terciptanya efisiensi (Manan, 1992).

Kekuatan ego-sektoral yang masih sangat melekat, menjadikannya sulit untuk membangun sinergi. Munculnya "gengsi" untuk melakukan kerjasama lintas kementerian, turut menjadi penyebab banyaknya regulasi yang justru tidak efisien (Febrian, 2015). Hal ini pula yang menurut pandangan Friedman (Friedman, 1975), perlu dilakukan penataan tiga aspek dalam upaya membangun sebuah legal sistem. Ketiganya antara lain adalah substansi (peraturan), struktur (kelembagaan) dan kultur (budaya/kebiasaan).

Apalagi secara normatif, telah ditegaskan dalam UU No. 39 Tahun 2008 juncto Perpres No. 68 Tahun 2019 untuk membangun koordinasi antar kementerian. Oleh karena itu, perlu 
dilakukan sebuah upaya dalam melakukan penguatan pemberdayaan desa melalui aspek regulasinya.

\section{Deregulasi Pengaturan Kelembagaan Desa sebagai Upaya Penguatan Pemberdayaan Masyarakat Desa}

Eksistensi otonomi desa, merupakan bagian yang tidak dapat terpisahkan dari karakter sebuah desa. Bahkan secara historis, otonomi desa selalu dinilai sebagai otonomi asli. Menjadi embrio dalam terbentuknya otonomi daerah (Herlina \& M. Yasin Nahar dan Surahman, 2017). Secara yuridis, berdasar pada Pasal 1 angka 12 UU No. 6 Tahun 2014, telah ditegaskan: Pemberdayaan Masyarakat Desa adalah upaya mengembangkan kemandirian dan kesejahteraan masyarakat dengan meningkatkan pengetahuan, sikap, keterampilan, perilaku, kemampuan, kesadaran, serta memanfaatkan sumber daya melalui penetapan kebijakan, program, kegiatan, dan pendampingan yang sesuai dengan esensi masalah dan prioritas kebutuhan masyarakat Desa.

Melalui upaya tersebut, diharapkan desa mampu mengembangkan wilayahnya, dengan didukung oleh sumber daya manusia tingkat desa yang berkualitas. Memberikan kesempatan kepada Desa, untuk lebih mandiri, khususnya melalui peran dari berbagai lembaga kemasyarakatan desa.

Eksistensi UU No. 6 Tahun 2014 juncto PP No. 43 Tahun 2016, secara filosofis dimaksudkan sebagai wujud pengakuan, perlindungan dan penguatan atas otonomi desa. Artinya, secara yuridis sebenarnya telah dibentuk suatu peraturan yang dimaksudkan untuk melakukan penataan kepada Desa secara integratif.

Namun, yang menjadi menarik adalah ketika mencermati pada Pasal 1 angka 16 dan penjelasan umum UU No. 6 Tahun 2014. Ditegaskan bahwa menteri yang menaungi Desa adalah menteri dalam negeri. Artinya, pada level undang-undang, telah menegaskan posisi Desa dinaungi oleh Kementerian Dalam Negeri.

Secara historis, kemunculan Kementerian Desa dan PDTT, memang di mulai pada Tahun 2014. Sebelumnya, kemeterian tersebut dikenal dengan Kementerian Negara Percepatan Pembangunan Kawasan Timur Indonesia. Munculnya Kementerian Desa dan PDTT, sebenarnya juga merupakan bagian dari program reformasi pembangunan di era pemerintahan Presiden Joko Widodo, yang membangun negara dari desa. Hal ini, turut menjadikan peran dan tugas antara Kementerian Desa dan Kementerian Dalam Negeri, bersinggungan. Masing-masing kementerian, turut mempunyai kewenangan yang sama dalam hal menyusun regulasi untuk Desa, khususnya dalam hal pemberdayaan desa.

Mencermati lebih lanjut ketentuan PermenDesa dan PDTT No. 17 Tahun 2019, serta Permendagri No. 18 Tahun 2018, yang memberikan pedoman pengaturan tentang peran lembaga kemasyarakatan Desa dalam melakukan pemberdayaan masyarakat desa. Namun, antara Pasal 6 dan 7 Permendagri No. 18 Tahun 2018, dengan Pasal 72 dan 73 PermenDesa dan PDTT No. 17 Tahun 2019, terdapat adanya kontradiksi kelembagaan, yaitu tentang lembaga pemberdayaan masyarakat. Permendagri No. 18 Tahun 2018 menyebut adanya lembaga pemberdayaan masyarakat, sedangkan dalam PermenDesa dan PDTT No. 17 Tahun 2019 tidak menyebut lembaga pemberdayaan masyarakat sebagai unsur pelaksana pemberdayaan masyarakat desa.

Hal tersebut menunjukkan adanya bentuk disharmonisasi, baik dalam konteks koordinasi kelembagaan, maupun harmonisasi dan sinkronisasi peraturan. Belum lagi jika berbagai peraturan menteri yang ada, tidak dapat langsung dilaksanakan oleh Desa, dengan dasar perlunya dibentuk peraturan lanjutan di tingkat Daerah Provinsi dan Daerah Kabupaten/Kota. Menunjukkan pula pada bentuk inkonsistensi atas hakikat pemberdayaan masyarakat desa. Di satu sisi hendak mengarahkan pada bentuk Desa mandiri, namun di sisi lain, membatasi dan memperlambat ruang gerak Desa untuk berkembang.

Dari segi teoritis, deregulasi merupakan bagian dari upaya pengurangan peraturan yang berorientasi pada efisiensi, optimalisasi, dan pertumbuhan ekonomi. Menghapus atau 
mengurangi beberapa aturan yang dinilai menghambat (Harseno, 2017). Dapat dipahami pula sebagai upaya untuk melakukan penataan ulang atas suatu peraturan perundang-undangan yang tidak efisien.

Faktanya, Indonesia dijuluki sebagai Negara yang "obesitas regulasi”. Setidaknya, pada tahun 2017 terdapat sekitar 62.000 peraturan yang dinilai dapat menghambat birokrasi, pelayanan publik, bahkan peluang investasi (Moh. Nadlir, 2017). Hal ini jelas memberikan dampak pada tersendatnya pembangunan, baik secara fisik maupun pembangunan sumber daya manusia. Pastinya turut berdampak pada pertumbuhan ekonomi nasional.

Pada kondisi ini, dengan mendasarkan pada upaya deregulasi, maka menjadi penting untuk melakukan pengurangan aturan yang justru menimbulkan polemik. Perlu dilakukan evaluasi pada tingkat peraturan menteri, yang dapat dilakukan melalui proses executive review.

Secara konseptual, executive review merupakan bentuk pengujian terhadap suatu peraturan perundang-undangan. Pengujian ini dilakukan untuk menilai substansi yang bertentangan dengan norma secara hirarkis dan kesesuaian implementasinya. Selama ini, proses executive review lebih banyak dilakukan terhadap peraturan daerah oleh Kementerian Dalam Negeri (Simatupang, 2019). Namun, berdasarkan tinjauan secara konseptual, tidak menutup kemungkinan dilakukan proses evaluasi Peraturan Menteri, khususnya yang berhubungan dengan pemberdayaan masyarakat desa dan kelembagaan desa, melalui tahap executive review.

Secara teknis, apabila proses ini dilakukan untuk melakukan evaluasi terhadap peraturan menteri, maka perlu ada keterlibatan dari Menteri Koordinator Bidang Politik, Hukum dan Keamanan. Mengingat, berdasar pada Pasal 2 ayat (1) Perpres No. 68 Tahun 2019, Menteri Koordinator melaksanakan fungsi sinkronisasi dan koordinasi urusan kementerian. Pertanggungjawaban dari pelaksanaan urusan executive review ini diserahkan kepada Presiden (Prabandani, 2015).

Apabila ditelusuri kembali, berdasarkan ketentuan peraturan perundang-undangan yang berlaku, khususnya mengenai pengujian peraturan perundang-undangan, terdapat pula proses judicial review. Secara konseptual, judicial review merupakan bentuk pengujian atas peraturan perundang-undangan yang dilakukan oleh badan/lembaga peradilan tertinggi (Mahkamah Agung dan Mahkamah Konstitusi) (Siahaan, 2020). Sesuai dengan kewenangannya, berdasarkan Pasal 24A UUD NRI 1945, maka kewenangan pengujian untuk peraturan yang berada di bawah undang-undang, dilakukan oleh Mahkamah Agung. Namun, apabila ditinjau dari aspek efektifitas penyelesaiannya, akan memakan waktu yang lebih lama.

Implikasi hukum yang ditimbulkan dari upaya deregulasi terhadap eksistensi otonomi desa, dapat memberikan penguatan pada desa dalam melakukan pemberdayaan masyarakat. Hal ini mengingat pula dalam program nawacita pemerintah saat ini, salah satunya adalah untuk percepatan pembangunan desa. Menjadi relevan, ketika dilakukan evaluasi dan pemangkasan atas peraturan yang menghambat tujuan tersebut.

Otonomi desa, dalam kerangka Negara Kesatuan Republik Indonesia memang perlu didukung dengan serangkaian program yang membantu mengarahkan pada pengembangan Desa (Nurcholis et al., 2019). Namun, sering kali program yang dikuatkan dalam peraturan perundang-undangan, justru berorientasi pada pembatasan ruang gerak Desa. Akibatnya, tujuan filosofis menjadi tidak teraktualisasikan.

Bukanlah suatu persoalan yang mudah, untuk melakukan deregulasi dari peraturan yang ada. Perlu dilakukan konsolidasi antar kementerian, bersama dengan Presiden, sehingga mampu melahirkan integrasi dan harmonisasi. Artinya, pada saat proses upaya deregulasi, juga harus diikuti dengan komitmen untuk membangun sinergi. Ketika evaluasi sudah dilakukan, dan ditemukan regulasi yang memang harus dicabut, langkah alternatif selanjutnya adalah melakukan penyusunan peraturan bersama antar kementerian. Peraturan bersama yang dimaksud, yaitu dengan menyesuaikan pada aspek yang serupa, misalnya tentang pemberdayaan masyarakat desa dan kelembagaan desa. 
Sebagai bahan pembanding, pada tahun 2020, telah diundangkan Undang-Undang Nomor 11 Tahun 2020 tentang Cipta Kerja (selanjutnya disebut UU No. 11 Tahun 2020. Secara konseptual, munculnya UU No. 11 Tahun 2020, dengan dasar Omnibus Law, merupakan bentuk penyatuan hukum atas satu bidang yang sama. Secara substansial, UU No. 11 Tahun 2020 memuat berbagai perubahan undang-undang, dengan tujuan dasar yaitu mempermudah investasi.

Menetapkan UU No. 11 Tahun 2020, tidaklah dilakukan dalam waktu yang singkat. Salah satunya telah dibuktikan sejak tahun 2017 ketika Negara Indonesia dinilai "obesitas regulasi". Meskipun UU No. 11 Tahun 2020 menuai banyak kontroversi, namun upaya tersebut merupakan bentuk pencapaian yang luar biasa, khususnya jika ditinjau dari aspek ilmu perundang-undangan. Keberhasilan pemerintah dan legislator dalam upaya melakukan penyederhanaan aturan.

Upaya deregulasi ini, juga perlu diikuti dengan penguatan peran sektoral kementerian. Hal ini dimaksudkan agar tidak menimbulkan dualisme tugas, fungsi dan kewenangan. Mengingat pula antara Kementerian Dalam Negeri dengan Kementerian Desa dan PDTT, mempunyai tupoksi yang serupa, khususnya dalam hal pemberdayaan masyarakat desa dan kelembagaan desa. Perlu juga diperhatikan kembali pada dasar Pasal 1 angka 16 dan penjelasan umum UU No. 6 Tahun 2014, yang menegaskan dalam naungan Kementerian Dalam Negeri. Artinya, mengingat terdapat Kementerian Desa dan PDTT yang sebenarnya secara khusus dimaksudkan untuk membantu pengembangan Desa, maka perlu juga dikuatkan perannya dalam tatanan undang-undangan.

Selain itu, kementerian lain seperti Kementerian Sosial, perlu juga membangun koordinasi dengan kedua kementerian tersebut. Salah satunya yang telah dibangun adalah melalui Permensos No. 25 Tahun 2019.

Melalui uraian tersebut, dapat ditarik sebuah pemahaman dengan didasarkan pada pemikiran Friedman tentang legal system. Pertama, perbaikan dan penataan substansi (regulasi) adalah pada upaya deregulasi, sehingga mampu menghasilkan sebuah pemberdayaan masyarakat yang relevan dengan semangat otonomi daerah melalui peran berbagai lembaga kemasyarakatan desa. Diikuti pula dengan menyusun peraturan bersama kementerian yang membidangi urusan tersebut.

Kedua, penataan struktur (kelembagaan), yaitu dengan peran dari Kementerian Koordinator Bidang Politik, Hukum dan Keamanan untuk melakukan proses executive review terhadap peraturan menteri terkait. Selain itu, perlunya penegasan atas kementerian yang memang menaungi segala bentuk urusan di Desa.

Ketiga, penataan kultur, yaitu dengan membangun pola hubungan kebiasaan koordinasi dan konsolidasi antar kementerian. Menghilangkan ego-sektoral, dan lebih fokus terhadap tujuan bersama untuk pembangunan nasional, khususnya dalam hal ini adalah pemberdayaan masyarakat desa melalui kelembagaan desa. Membiasakan untuk membangun sinergitas penyusunan regulasi yang tidak tumpang tindih dan aplikatif. Melakukan pembinaan secara terpadu, yang secara khusus dikoordinasikan melalui satu kementerian.

\section{Simpulan}

Secara normatif, berdasar pada UU No. 39 Tahun 2008 juncto Perpres No. 68 Tahun 2019, penyusunan peraturan menteri di setiap bidang, untuk satu aspek tentang peran kelembagaan desa dan pemberdayaan desa memang dimungkinkan. Namun, disisi lain terdapat adanya egosektoral yang menjadikan antar kementerian belum mampu membangun sinergitas dalam penyusunan peraturannya, khususnya antara Kementerian Dalam Negeri dengan Kementerian Desa dan PDTT.

Upaya deregulasi terhadap peraturan yang berhubungan dengan kelembagaan desa, khususnya lembaga kemasyarakatan desa menjadi alternatif dalam penguatan pemberdayaan masyarakat desa. Hal ini mengingat, bahwa secara normatif berdasar pada UU No. 6 Tahun 2014, pemberdayaan masyarakat desa dilakukan melalui peran lembaga kemasyarakat desa. 
Artinya apabila dilakukan deregulasi tersebut, maka dapat berimplikasi pada efektivitas pelaksanaannya. Namun, tetap harus diikuti dengan adanya komitmen lembaga dalam melakukan koordinasi dan konsolidasi. Tidak menutup kemungkinan, juga dilakukan penyusunan peraturan bersama antar kementerian untuk satu aspek yang serupa.

\section{DAFTAR PUSTAKA}

Barniat, Z. (2019). Otonomi Desa : Konsepsi Teoritis Dan. Jurnal Analisis Sosial Politik, 5(1), $20-33$.

Chandranegara, I. S. (2019). Bentuk-Bentuk Perampingan dan Harmonisasi Regulasi. Jurnal Hukum Ius Quia Iustum, 26(3), 435-457. https://doi.org/https://doi.org/10.20885/iustum.vol26.iss3.art1

Febrian, R. A. (2015). Analisis Permasalahan Koordinasi Pemerintahan (Tinjauan Konseptual Dan Teoritis). Journal of Chemical Information and Modeling, 1(1), 41-49.

Friedman, L. M. (1975). The Legal System, A Social Science Perspective. Russell Sage Foundation.

Harseno, R. M. (2017). Kebijakan Deregulasi dan Debirokratisasi Regulasi Ekonomi Kemariman sebagai Katalisator Nawacita Indonesia Poros Marim Dunia. Gema Keadilan, 4(September), 93. https://ejournal2.undip.ac.id/index.php/gk/article/view/3773/2111

Herlina, H. ; \& M. Yasin Nahar dan Surahman. (2017). Undang-Undang Republik Indonesia, Nomor 6 Tahun 2014 Tentang Desa. E Jurnal Katalogis, 5(5), 111-121.

Manan, B. (1992). Dasar-Dasar Perundang-undangan. Ind-Hill.

Maschab, M. (2013). Politik Pemerintahan Desa di Indonesia. PolGov, Research Centre For Politics and Government, Department of Politics and Government.

Moh. Nadlir. (2017). Ada 62.000 Aturan, Indonesia Dianggap Obesitas Regulasi. Kompas.Com. https://nasional.kompas.com/read/2017/11/10/19062511/ada-62000-aturan-indonesiadianggap-obesitas-regulasi?page $=$ all

Noviantika, T., \& Taufiq, M. S. (2021). Eksistensi Kementrian Negara dalam Sistem Presidensil Berdasarkan Undang-Undang Nomor 39 Tahun 2008 Tentang Kementrian Negara. Jurnal Muhammadiyah Law Review, 5(1), 1-6.

Nurcholis, C., Sakti, S. W. K., \& Rachman, A. S. (2019). Village Administration in Indonesia: A Socio-Political Corporation Formed by State. Open Journal of Political Science, 09(02), 383-404. https://doi.org/10.4236/ojps.2019.92021

Pakaya, J. S. (2016). Pemberian Kewenangan Pada Desa dalam Konteks Otonomi Daerah (The Providing of Authority to Village in the Context of Regional Autonomy). Jurnal Legislasi Indonesia, 13(1), 73-84.

Pamuji, K. . et. a. (2017). Pengembangan Model Partisipasi Masyarakat Dalam Penyelenggaraan Pemerintahan Desa Di Kabupaten Banyumas. Jurnal Hukum Ius Quia Iustum, 24(4), 625643. https://doi.org/10.20885/iustum.vol24.iss4.art6

Prabandani, H. W. (2015). ( CONSTITUTIONAL LIMITS OF THE PRESIDENTIAL EXECUTIVE POWER ) Hendra Wahanu Prabandani Biro Hukum Badan Perencaanaan Pembangunan Nasional Jln . Taman Suropati No . 2 , Gedung TS 2A 1t . 4 , Jakarta Pusat, 10310 Indonesia Pendahuluan Indonesia telah menet. Jurnal Legislasi Indonesia, 12(3), 1- 
27.

Siahaan, M. (2020). Integrasi Konstitusional Kewenangan Judicial Review Mahkamah Konstitusi dan Mahkamah Agung. Jurnal Konstitusi, 17(4), 729-752. https://doi.org/10.31078/jk1742

Simatupang, T. H. (2019). Mendudukkan Konsep Executive Review dalam Sistem Hukum Ketatanegaraan Indonesia. Jurnal Penelitian Hukum De Jure, 19(2), 217-230. https://doi.org/10.30641/dejure.2019.v19.217-229

Suharto. (2018). Pemberdayaan Masyarakat Desa Dalam Implementasi UU Desa (Analisis Implementasi UU No.6 Tahun 2014 Tentang Desa). Prosiding Senas POLHI Ke-1 Tahun 2018 Fakultas Ilmu Sosial Ilmu Politik Universitas Wahid Hasyim Semarang, 1, 47-65.

Syafi'ie, M. (2012). Instrumentasi Hukum Ham, Pembentukan Lembaga Perlindungan Ham Di Indonesia Dan Peran Mahkamah Konstitusi. Jurnal Konstitusi, 9(4), 681-712. 